\title{
LEGAL ENFORCEMENT OF TEACHER EDUCATION IN GREAT BRITAIN
}

\begin{abstract}
The article deals with legal enforcement of teacher education in Great Britain. It has been found out that in Great Britain, the sources of education legislation are statutes and acts adopted by British government. All current statutes relating to education are classified either as public or private. Public laws contain general rules, that is, designed for all individuals and for repeated application. They operate throughout the country, addressed to all subjects of educational relations. Private statutes accumulate private norms, which refer to specific legal entities or individuals and contain strictly defined directives for them. They are addressed to a particular country or specific organization or group of individuals. It has been indicated that the system of education legislation in Great Britain in the context of teacher education is provided by a range of legal acts, such as the Education Reform Act of 1988, the Further and Higher Education Act of 1992, by the Teaching and Higher Education Act of 1998, The Education Act 2002, The Education Act of 2005, The Education and Inspections Act of 2006, The Education and Skills Act of 2008, The Education Act of 2011, The Education and Adoption Act 2016, The Higher Education and Research Act 2017 as well as legal acts of European authorities. It has been concluded that the orientation of the content of British legal acts toward quality teacher training should be successfully implemented into Ukrainian education legislation so that the national system of teacher training may be improved. It has been suggested that the prospects for further researchers are seen in studying the legal enforcement of teacher education in leading European countries (Sweden, the Netherlands, Germany, France, Switzerland etc.).
\end{abstract} institution

Keywords: legal enforcement, Great Britain, education, teacher, higher education

\section{INTRODUCTION}

Under the conditions of globalization processes in the socio-cultural environment and interdependence of world countries, there appear new requirements for the level of the system of Ukrainian education. The process of Ukrainian education system's integrating into the European and global educational space is associated with reconsideration of accumulated experience, the search for mechanisms for adapting positive foreign experience to modern realities. Comparative researces on pedagogy allow identifying those problems and changes taking place in Ukrainian teacher education in the context ofglobal trends. Despite certain differences in historical, social and cultural aspects of Great Britain and Ukraine, the functional community of national pedagogical systems enables creative using the experience of teacher training in Great Britain and contributes to improving the system of Ukrainian teacher education in general.

It must be noted that the problem of professional teacher training is considered as one of the most urgent in Great Britain. Over the last decades, British government has 
adopted a series of acts aimed at modernizing professional training of teachers. The acts emphasize the leading role of the teacher in solving educational and learning problems and pay special attention to the system of teacher training and advanced teacher training.

\section{THE AIM OF THE STUDY} Great Britain

The aim of the study is to analyze legal enforcement of higher teacher education in

\section{THEORETICAL FRAMEWORK AND RESEARCH METHODS}

The aspects on legal enforcement of teacher education in Great Britain have been covered by Ukrainian and British scholars (N. Avsheniuk (2005), A. Bathmaker (2003), C. Chitty (2004), V. Duckworth (2014), D. Gillard (2011), R. Hyland (2002), T. Kuchai (2009), D. Morris (2017) et al.). It must be noted that the works by abovementioned scholars have greatly contributed to achieving the aim of the study. Yet, the materials of UK legislation have become of great significance. In particular, we have considered "The 1902 Education Act", "The Education Act of 1944", "The Education Reform Act 1988", "The Further and Higher Education Act 1992", "The Teaching and Higher Education Act 1998", "The Education Act 2002", "The Education Act 2005", "The Education and Inspections Act 2006", "The Education and Skills Act 2008", "The Education Act 2011", "The Education and Adoption Act 2016", "The Higher Education and Research Act 2017; the documents by the Department for Education, namely, "The Importance of Teaching: the Schools White Paper", "Training our next generation of outstanding teachers. Implementation plan" as well as by Ofsted - The Framework for School Inspection; Circular 9/92 (1992) on Initial Teacher Training etc.

The problem of legal enforcement of teacher education in Great Britain has been studied due to the use of such methods as systematic study of legal documents, their analysis and synthesis, that has allowed drawing relevant conclusions using systematization and generalization.

\section{RESULTS}

In Great Britain, the sources of education legislation are statutes and acts adopted by British government. All current statutes relating to education are classified either as public or private. Public laws contain general rules, that is, designed for all individuals and for repeated application. They operate throughout the country, addressed to all subjects of educational relations. Private statutes accumulate private norms, which referto specific legal entities or individuals and contain strictly defined directives for them. They are addressed to a particular country or specific organization or group of individuals.

Among the sources of British education legislation are declarations, conventions and other acts adopted by the United Nations and its specialized agencies, as well as educational agreements concluded by that country with other ones. In this case, the basic norms of international law on education are contained in the Universal Declaration of Human Rights adopted by the United Nations in 1948, the International Covenant on Civil and Political Rights and the International Covenant on Economic, Social and Cultural Rights - in 1956. These documents proclaim the right to education as an inalienable human right and establish the provision that, at the level of primary and general education, it should be free of charge.

British actsensure equality of educationalopportunity, namely, creation of education system and relevant socioeconomic conditions for obtaining education; education availability; provision of developmental disorders correction and social adaptation based on specific pedagogical approaches for children with learning disabilities. The right to education is also a form of human freedom in education (Library of Congress, 2016). 
The Balfour Act of 1902 established a nationally coordinated system of education in England and Wales based on local governance, supporting partnerships with central administration.Local education authorities (LEAs) were created and were aimed at ensuring funding for schools and gymnasiums. This law was of great significance since it enabled all schools, including denominational ones, to receive funding from local budgets (Spartacus Educational, 2017).

In 1944, the Butler's Act of 1944 was adopted, which many scholars regarded as one of the most progressive education laws, and brought England and Wales closer to European practice. The Act provided for raisingcompulsory school age from 14 to 15 years old; implementation of free education in public schools; establishment of three types of schools - grammar schools, secondary technical schools and secondary modern schools (Parliament UK, 1944).

Regarding school teachers and organization of teacher professional training, we would like to highlight the following provisions of the law: the Ministry of Education and local education authorities should beresponsibile for teacher professional training (the government used to regulate teacher training, yet it did not control its organization); teacher discrimination should be prohibited; teacher salary scheme should be unified for all types of school. In addition to the law, they established qualification differences between primary and secondary school teachers. The law clearly regulated the system of education management at all levels, financing for educational institutions, division of responsibilities between parents and educational institutions for learning and upbringing of children.It should be noted that these innovations were implemented in practice rather slowly (Parliament UK, 1944).

The study on the history of teacher education in Great Britain shows that in the mid-20th century the system of teacher training largely expanded. This occurred because of reforming the national school education system, developing secondary education in general, socioeconomic requirements etc. The Butler's Act had contributed to outlining all institutions providing teacher training and establishing a network of interconnections between them. British teacher education institutions consisted of three categories: a) training colleges; b) university training departments; c) specialist colleges for art teachers (Institute of Historical Research, 2010).

In Great Britain, education standards are developed and operatebased on the National Curriculum (NC) following the Education Act of 1988 and being implemented during 1991-1995.

The peculiarities of English education standards are the following: 1) the standard provides for advanced goals and levels for university studies; 2) the amount of time allocated to all subjects is determined bythe educational institution; 3) the standard stipulates that the NC should comprise $70-75 \%$ of total learning time; 4) the standard ensures continuity and successionof education through gradual structure of courses and regular monitoring of learning outcomes; 5) the standard defines the number of sections and their content for each stage; 6) the standard ensures variability and differentiation of learning (different approaches are applied to different subjects), namely, there arecore study units and supplementary units (Kuchai, 2009).

It must be noted that the $\mathrm{NC}$ emphasized the need for increasing the level of education. Consequently, the new law fundamentally changed the entire system of primary and secondary education in England and Wales. It stipulates four main components based on the concepts of the National Curriculum, local school self-government, definition of the status of direct subsidies to schools and the concept of local technology colleges. British 
educators indicate that the education reform in the late 1980s was aimed at raising the level of secondary education through mandatory introduction of education standards for school education. Thus, one can understand the system of teacher training only through the prism of comprehension of the content of school education in Great Britain (Chitty, 2004; Gillard, 2011).

The Department for Education gradually strengthened centralization of the education system management, sought funds for development of school networks, developed requirements for the content of learning, etc. The education system, established by the Education Act of 1944, was in force until the adoption of the Education Actof 1988 (UK Legislation, 1988). It must be noted that 1988 became a turning point in the whole system of education in Great Britain, since the Education Reform Act was adopted, which envisaged reforms in all educational institutions, including teacher education institutions.

The Education Reform Act of1988 covered all levels of education - from primary schools to higher education. The major reforms of higher education concerned implementation of the changes proposed in 1987 in the White Paper, namely, the control of higher and further education provision was taken out of Local Authority control. In 1989 higher education funding councils were founded. As one can see, gradual unification of higher education took place. The Act abolished the binary system (or binary divide), allowing polytechnics to assume the title of 'university' (Oxford Reference, 1992).

In the late 1980s, the Department for Education published the Education (Teachers) Regulations 1989and Initial Teacher Training: Approval of Courses, which can be considered as the beginning of modern reforming teacher education in Great Britain.

In May 1991, British government issued the White Paper Higher Education: a New Framework, in which they proposed a number of changes in the system of higher education. This document became the basis for adopting the Further and Higher Education Actof 1992, therefore some reforms in higher education have been initiated, namely,the unified higher education system was established as well as new funding councils (Higher Education Funding Council for England, Wales and the Scottish Further and Higher Education Funding Council); polytechnics became independent universities which meant they could award their own degrees; the Higher Education Quality Council (or the Committee of Vice-Chancellors and Principals) and quality assessment divisions were established; master and doctoral programmes were improved; access to higher education was expanded; quality of specialists' training was increased; external monitoring of specialists' training was launched (Bathmaker, 2003).

The UK Secretary of State for Education K. Clarke proclaimed the main provisions of the reform on January 4, 1992 in a speech to the North of England Education Conference. He highlighted the following areas of the government policy in teacher education: the priority role of school in professional teacher training; introduction of approved curricula and basic teacher training programmes; definition of criteria for professional teacher training in teacher education institutions (Hyland, 2002).The official document of these innovations was the Circular No 9/92 "Initial Teacher Training" (1992) developed by the Department for Education, which specified new criteria and procedures in England and Wales for the accreditation of courses of initial teacher training (Education in England, 1992).

In 2000, British government established General Teaching Council for England. It was first mentionedin the circular No 4/98 "Teaching, High Status, High Standards, Requirements for Courses of Initial Teacher Training, focused on the functions of this professional organization and the aim of its establishment. In the memorandum to the document, there are the main provisions reflecting the government's initiative. In particular, 
it is noted that establishment of General Teaching Council for Englandis a rather necessary innovation. The main aim of establishing such an organization is to strengthen the position of teachers by providing them with professional status. On the one hand, it would act as a guarantor of certain autonomy, and on the other hand, it would encourage the teacher community to work with the government to enhanceeducation standards.

The legitimacy of the General Teaching Council for Englandwas approved by the Teaching and Higher Education Act of 1998, which indicated its key functions as an institution independent of the government: to uphold the rights of teaching as a profession; promote enhancing standards of school education; to assist in selecting the right applicants for teaching (to develop standards on psychophysical suitability for the profession); to register qualified teachers; to introduce sanctions against unprofessional behaviour and incompetence; to provide guidance on employment and remuneration of teachers, initial teacher training, further professional development etc. (Avshenyuk, 2005; UK Legislation, 1998).

The General Teaching Council for England has been entitled to register all qualified teachers working in public schools, pupil referral units and non-maintained special schools. The registration was, on the one hand, aimed at creating a comprehensive database, which contains detailed information about all qualified teachers. The information collected is used by the General Teaching Council for England to provide the government with guidance on professional activities of teachers and employers - with the data on the level of teachers'qualification and suitability for professional activities.

On the other hand, it has enabled the General Teaching Council for England to fulfill its key function - to establish standards for teachers' professional activity and ensure their effectiveness. Over the past few years, the Professional Standards Committee has been functioning within this organization, which develops standards that regulate teaching. At present, two such documents as the Code of Conduct and Practice) and the Code of Values and Practice have been introduced into the practice of teacher education (Avshenyuk, 2005).

The Education Act 2002 distinguished the following aims of education legislation: to ensure protection of childhood within Great Britain and establish appropriate services; to provide financial support for those who are studying; to organize training of teaching and non-teaching staff. This document defines the main objective of education legislation, namely, to entitle every British citizen to obtain quality education etc. (UK Legislation, 2002).

In the context of standard-oriented reforms inteacher education that have been implemented in England and Wales over the past decades, the functions of establishing and monitoring the realization of standards for professional training and teaching are performed by public authorities. Thus, the establishment ofthe General Teaching Council for Englandis considered being restoration of the right of the profession to influence the processes of teacher education management. This primarily involves providing this organization with advisory functions in defining standards for professional activity and monitoring the results on their implementation.

The issue of teacher training modernization was addressed on February 26, 2004 by the Council of Europe and the European Commission, which resulted in the adoption of the document entitled "Education \& Training 2010 - The Success of the Lisbon Strategy Hinges on Urgent Reforms", in which the competencies and qualifications that future teachers who will work in the pan-European educational space must obtain have been published. The document noted that the teacher is an organizer of modern changes and reforms in society that will make the European Union's economy one of the most effective in the world. Therefore, the teacher must participate in restructuring "knowledge society", 
as well as stimulate the students to pursue sustainable professional development. As for the requirements for the teacher, they are the following: the teachers should conduct relevant researchers, master new teaching methods, engage in self-education, improve the content of the curriculum, develop innovative methods.

In September 2007, the Standards for the Award of Qualified Teacher Status were revised. We characterize it. Thus, they include three sections: 1) professional attributes; 2) professional knowledge and understanding; 3) professional skills.

The Education Act of 2005 was the key regulatory document that laid the foundation for reforms in quality management. The Act envisaged introduction of a new reporting framework for schools, which considered internal assessment to be central in monitoring. Her Majesty's Chief Inspectors of Schools was entrusted with the responsibility to bring to the attention of the Chief Minister of the Department of Education the information on the developedprocedure of school inspection (UK Legislation, 2005).

The Education and Inspections Act of 2006 "is intended to represent a major step forward in the Government's aim of ensuring that all children in all schools get the education they need to enable them to fulfil their potential". The Act is designed to give greater freedoms to schools, including the possibility of owning their own assets; employing their own staff; setting their own admissions arrangements. Other important provisions include creation of a local authority duty to promote fair access to educational opportunities; giving schools staff a clear statutory right to discipline students; reform of the school inspectorates, etc. (UK Legislation, 2006).

The Education and Skills Act of 2008 is the Act of the Parliament of the United Kingdom that raised the minimum age at which a person can leave education or training to eighteen for those born after 1 September 1997, with an interim minimum leaving age of 17 from 2013 (UK Legislation, 2008). The Act also introduced a number of other changes including the right of choice and appeal for young people regarding their sixth form college, and placing duties on the Learning and Skills Council regarding payment and finance of courses for both children and adults. In addition, the Act sets out that from 2015 all 16- and 17-years olds will be required to participate in education or training. The eligible forms of education or training for young people to participate are appropriate fulltime education or training; a contract of apprenticeship or part-time education or training towards an accredited qualification as part of full-time occupation or alongside occupation of more than 20 hours a week (Duckworth, 2013).

During 2010-2015, Great Britain has undergone significant changes in education legislation, which led to a series of reforms in teacher training. The details of the reforms are reflected in the document entitled "Training Our Next Generation of Outstanding Teachers: Implementation Plan" (2011). The document states that nothing is more important to the quality of education than the quality of the teacher. Therefore, teaching is the most prominent profession respected in the whole society.

In the document entitled "The Importance of Teaching: the Schools White Paper", they recognize that British schools today have the best generation of teachers they have ever had. In addition, they outline a comprehensive program to improve teacher training, including structural reforms, curriculum and qualifications reform, clear accountability and strengthening authority of teachers and school leaders. However first and foremost, they believe that they must continue training and further improving teachers' professional skills (Department for Education, 2010).

The Education Act of 2011 has made changes to many areas of educational policy, including the power of school staff to discipline students, the manner in which newly 
trained teachers are supervised, the regulation of qualifications, the administration of local authority maintained schools, academies, the provision of post-16 education, including vocational apprenticeships, and student finance for higher education. The Act also brought about the abolition of the General Teaching Council for England, the Qualifications and Curriculum Development Agency and the Training and Development Agency for Schools, amongst other bodies (UK Legislation, 2011).

The Framework for School Inspection was adopted in 2013. The document notes that a school will be notified of its inspection at or after midday on the working day before the start of the inspection. However, HMCI reserves the right to inspect any school without notice where this is judged to be appropriate. Inspectors may use a range of evidence for the initial identification of issues to be followed up in inspection, including performance data, the school's previous inspection report, any recent Ofsted survey reports and/or monitoring letters, and information from Parent View (Ofsted, 2013).

When judging the overall effectiveness of the school and when making the four key judgements about the achievement of pupils, the quality of teaching, the behaviour and safety of pupils, and the quality of leadership in, and management of, the school, inspectors use the following scale: grade 1: outstanding; grade 2: good; grade 3: requires improvement; grade 4: inadequate. In judging the school's overall effectiveness, inspectors will consider whether the standard of education is 'good' (grade 2), or exceeds this standard sufficiently to be judged as 'outstanding' (grade 1); whether the school 'requires improvement' as it is not yet a 'good' school, because one or more of the four key judgements is 'requires improvement' (grade 3), and/or there are overall weaknesses in the provision for pupils' spiritual, moral, social and cultural development; whether the school is 'inadequate' (grade 4) and, if so, whether it has serious weaknesses or requires special measures (Ofsted, 2013).

The Education and Adoption Act 2016 gives the government new powers to intervene more rapidly in schools rated by Ofsted as "inadequate" or "coasting" and speed up the process of converting failing comprehensive schools into academies. The measures in the Act are also designed to speed up the adoption process by the Secretary of State requiring local authorities to make arrangements for their adoption functions (recruitment, assessment and approval) to be carried out by another adoption agency. The Act makes amendments to the Education Act 2011, Academies Act 2010, Education and Inspections Act 2006 (UK Legislation, 2016).

The Higher Education and Research Act 2017 was enacted into law in the United Kingdomby the Houses of Parliament on 27 April 2017 (David, 2017). It is intended to create a new regulatory framework for higher education, increase competition and student choice, ensure students receive value for money, and strengthen the research sector.The Act is a replacement for the Further and Higher Education Act 1992 and is intended to accommodate subsequent changes in the higher education sector. The Act is split into four parts: Part 1 establishes the Office for Students and gives it responsibilities for regulating the Higher Education sector; Part 2 amends prior legislation on student financial support and student complaints procedures; Part 3 establishes a body called United Kingdom Research and Innovation and gives it responsibilities for regulating and funding research; and Part 4 addresses miscellaneous issues such as transitional arrangements and data sharing (UK Legislation, 2017).

CONCLUSIONS

The system of education legislation in Great Britain in the context of teacher education is provided by a range of legal acts, such as the Education Reform Act of 1988, 
the Further and Higher Education Act of 1992, by the Teaching and Higher Education Act of 1998, The Education Act 2002, The Education Act of 2005, The Education and Inspections Act of 2006, The Education and Skills Act of 2008, The Education Act of 2011, The Education and Adoption Act 2016, The Higher Education and Research Act 2017 as well as legal acts of European authorities. In our opinion, the orientation of the content of British legal acts toward quality teacher training should be successfully implemented into Ukrainian education legislation so that the national system of teacher training may be improved.

The prospects for further researchers are seen in studying the legal enforcement of teacher education in leading European countries (Sweden, the Netherlands, Germany, France, Switzerland etc.).

\section{REFERENCES}

1. Avsheniuk, N. (2005). Standartyzatsiia profesiinoi pidhotovky vchyteliv $u$ Anhlii y Uelsi (kinets XX - pochatok XXI st.). (Dys. kand. ped. nauk). Instytut pedahohiky i psykholohii profesiinoi osvity Akademii pedahohichnykh nauk Ukrainy, Kyiv.

2. Bathmaker, A. (2003). The expansion of higher education: a consideration of control, funding and quality. InS. Bartlett \& D. Burton (Eds.), Education Studies. Essential Issues (pp. 169-189). London: Sage.

3. Chitty, C. (2004). Education policy in Britain. Basingstoke: Palgrave Macmillan.

4. Department for Education. (2010). The importance of teaching: the schools white paper. Retrieved from https://www.gov.uk/government/uploads/system/uploads/ attachment_data/file/ 175429/CM-7980.pdf.

5. Department for Education. (2011). Training our next generation of outstanding teachers. Implementation plan. Retrieved from https:/www.gov.uk/government/uploads/ system/uploads/attachment_data/file/181154/DFE-00083-2011.pdf.

6. Duckworth, V. (2014). How to be a brilliant FE teacher. New York. NY: Routledge.

7. Education in England. (1992). Circular 9/92 (1992). Initial Teacher Training (Secondary Phase). Retrieved from http://www.educationengland.org.uk/documents/des/cir cular9-92.html.

8. Gillard, D. (2011). Education in England: a briefhistory. Retrieved from http://www.educationengland.org.uk/history/chapter08.html.

9. Hyland, R. (2002). Why children's perceptions? The context for the inquiry. In H. Copper \& R. Hyland (Eds.), Children's perceptions of learning with trainee teachers (19-31). London; New York, NY: RoutledgeFalmer.

10. Institute of Historical Research. (2010). Teacher training up to the 1960s. Retrieved from https://www.history.ac.uk/history-in-education/sites/history-in-education/files/ attachments/teacher_training_-_up_to_the_1960s.doc.

11. Kuchai, T. (2009). Pidhotovka maibutnikh uchyteliv v universytetakh Velykoi Brytanii do ekolohichnoho vykhovannia uchniv. (Dys. kand. ped. nauk). Bohdan Khmelnytskyi National University of Cherkasy, Cherkasy.

12. Library Congress. (2016). Constitutional right to an education: England and Wales. Retrieved from https:/www.loc.gov/law/help/constitutional-right-to-an-education/ englandandwales.php.

13. Morris, D. (2017). Be it enacted: the Higher Education and Research Act. Retrieved from http://wonkhe.com/blogs/be-it-enacted-the-higher-education-and-researchact-2017/. 
14. Ofsted. (2013). The Framework for School Inspection. Retrieved from https://www.jogobehavioursupport.com/getdocument.php?d=pdfs/docs_and_guidance\&f=T he framework_for_school_inspection_Jan_2013.pdf.

15. Oxford Reference. (1992). Further and Higher Education Act 1992. Retrieved from http://www.oxfordreference.com/view/10.1093/oi/authority.20110803095839655.

16. Parliament UK. (1944). The Education Act of 1944. Retrieved from http://www.parliament.uk/about/living-

heritage/transformingsociety/livinglearning/school/overview/educationact1944/.

17. Spartacus Educational. (2017). 1902 Education Act. Retrieved from http://spartacus-educational.com/Leducation1902.htm.

18. UK Legislation. (2016). Education and Adoption Act 2016. Retrieved from http://www.legislation.gov.uk/ukpga/2016/6/contents/enacted.

19. UK Legislation. (2002). Education Act 2002. Retrieved from https://www.legislation. gov.uk/ukpga/2002/32/contents.

20. UK Legislation. (2005). Education Act 2005. Retrieved from https://www.legislation. gov.uk/ukpga/2005/18/contents.

21. UK Legislation. (2011). Education Act 2011. Retrieved from http://www.legislation. gov.uk/ukpga/2011/21/contents/enacted.

22. UK Legislation. (2006). Education and Inspections Act 2006. Retrieved from https://www.legislation.gov.uk/ukpga/2006/40/contents.

23. UK Legislation. (2008). Education and Skills Act 2008. Retrieved from https:/www.legislation.gov.uk/ukpga/2008/25/contents.

24. UK Legislation. (1988). Education Reform Act 1988. Retrieved from http://www.legislation.gov.uk/ukpga/1988/40/contents.

25. UK Legislation. (2017). Higher Education and Research Act 2017. Retrieved from http://www.legislation.gov.uk/ukpga/2017/29/contents/enacted.

26. UK Legislation. (1998). Teaching and Higher Education Act 1998. Retrieved from http://www.legislation.gov.uk/ukpga/1998/30/contents. 